\title{
Does A Correlation Exist Between Fluid Intelligence And Creativity?
}

\author{
Nakşidil Torun YAZIHAN ${ }^{1}$
}

\begin{abstract}
The aim of the study was to investigate the associations between fluid intelligence and creativity among young adults. The sample consisted of 26 university students who were recruited through convenience sampling method. The Raven Standard Progressive Matrices (RSPM) 9 item-form and a divergent thinking test were used to measure fluent intelligence and creativity, respectively. In order to examine the associations between creativity and fluent intelligence correlational analysis was applied. The Pearson's correlation coefficient revealed that there was no significant relationship between the tests of divergent thinking and RSPM total score. On the other hand, the results showed a significant positive correlation between the RSPM visuospatial factor and both fluency $(\mathrm{r}=.47, \mathrm{p}<.01)$ and flexibility $(\mathrm{r}=.41, \mathrm{p}<.01)$ dimensions of the divergent thinking test. As a result, we suggest that certain basic processes regarding fluid intelligence (e.g. visual spatial reasoning) and creativity operate through common and similar mechanisms. Future studies could investigate the association between these constructs by using neuro-imagining method and focus on how these skills can be integrated into real life situations.
\end{abstract}

Key Words: Fluent Intelligence, Creativity, Divergent Thinking, Creative Thinking

\section{Akışkan Zeka ve Yaratıcılık Arasında Bir İlişki Var Mıdır?}

Özet: Bu çalışmanın amacı genç yetişkenlerde yaratıcılık ve akışkan zeka arasında nasıl bir ilişki olduğunu araştırmaktır. Elverişli örneklem yöntemi ile veri toplanmış; örneklem 26 üniversite öğrencisinden oluşmuştur. Katılımcılara akışkan zeka ve yaratıcılığı değerlendirmek üzere sırasıyla Raven Standart Progresif Matrisler (RSPM) 9 maddelik form ve diverjant düşünme testi uygulanmıştır. Yaratıcılık ve akışkan zeka arasında bir bağlantı olup olmadığının araştırılmasında korelasyonel yöntem kullanılmıştır. Pearson korelasyon katsayısılarına göre RSPM toplam puan ve diverjant düşünme sonuçları arasında bir ilişki bulunamamıştır. Alt boyutlar incelendiğinde, RSPM testinin görsel-uzamsal faktörü ile diverjant düşünme testinin akıc1lı (r=.47, $\mathrm{p}<.01)$ ve esneklik ( $\mathrm{r}=.41, \mathrm{p}<.01)$ boyutları arasında pozitif yönlü anlamlı ilişki elde edilmiştir. Sonuç olarak, akışkan zeka (örn., görsel uzamsal muhakeme) ve yaratıcılıkla ilişkili belirli temel süreçlerin ortak ve benzer mekanizmalar üzerinden işlediğini söyleyebiliriz. Ayrıca, yaratıcılığın ve akışkan zekanın değerlendirilmesinde kullanılan malzemeye bağlı olarak bu ilişkinin değişebileceğini düşünüyoruz. Gelecekteki çalışmaların bu yapıları nörogörüntüleme yöntemi kullanarak araştırabileceği ve söz konusu becerilerin günlük hayata nasıl entegre edilebileceği üzerine odaklanabileceği düşünülmektedir.

Anhtar Kelimeler: Akışkan Zeka, Yaratıcılık, Diverjant Düşünme, Yaratıcı Düşünme

${ }^{1}$ Dr. Çankaya Üniversitesi, Psikoloji Bölümü, Türkiye-Ankara

Address of correspondence/Yazışma adresi: Dr. Nakşidil Torun Yazıhan, Çankaya Üniversitesi, Psikoloji Bölümü, Türkiye-Ankara, E-mail: naksidil.yazihan@gmail.com

Date of Received/Geliş Tarihi: 07.09.2019, Date of Revision/Düzeltme Tarihi: 03.11.2019, Date of Acceptance/Kabul Tarihi: 10.02 .2020

Citing/ Referans Gösterimi: Yazıhan, N.T. (2020). Does A Correlation Exist Between Fluid Intelligence And Creativity?, Klbris Türk Psikiyatri ve Psikoloji Dergisi, 2 (1): 28-34 doi:10.35365/ctjpp.20.2.4 


\section{Introduction}

A large number of studies in the broader literature have examined the relationship of creativity and intelligence. Interestingly, however, studies in this area still have inconsistent results. While one theory claims that intelligence is necessary, but not the only necessity for creativity (Barron 1969), other theories suggest that very high intelligence can interfere with creativity (Sternberg 1996) or is one of the components of intelligence (Plucker, Esping, Kaufman, \& Avitia, 2014).

The construct of fluid intelligence is defined as the ability to flexibly deduce rules, to think logically, to reason and to think abstractly (Cattell, 1967). Fluid intelligence is a complex ability which found to be associated with a wide variety of cognitive tasks. It is critical in adapting to new situations efficiently and plays a critical role in generating solutions to the problems encountered (Gray \&Thomson, 2004). On the other hand, creativity is considered as an ability or process that emerges as an original, valuable and socially accepted idea or product. It involves unique, useful, and productive thought and behaviour (Sternberg \& Lubart, 1996; Sternberg \& Kaufman, 2011). Other characteristics of this process include the ability to re-establish the conceptual structures, visualization during creative idea generation, inhibition of competing ideas, and the sudden occurrence of a solution during problem solving (Abraham \& Windmann, 2007).

Since a long time, divergent thinking tests have been used to measure creativity psychometrically (Shi, Wang, Yang, Zhang \& Xu, 2017). According to Guilford (1967), divergent thinking is characterized by creating original combinations, using existing knowledge and generating new approaches and original ideas through skills such as flexibility and fluency.

On the other hand, fluid intelligence has often been measured psychometrically by RSPM (Raven Standard Progressive Matrices) and among many of the neuropsychological tools, it is one of the most extensively administered tests in the literature to measure fluid intelligence (Bilker, Hansen, Brensinger, Richard, Gur \& Gur, 2012; Downey, Lomas, Billings, Hansen, \& Stough, 2014). The test is popular because of various reasons such as it was designed specifically to measure Spearman's general ability factor and it has also been used widely as an assessment tool to measure fluid intelligence (Spearman \& Wynn-Jones, 1951).

The RSPM measures abilities to infer and integrate rules, to manage goal hierarchies and to form abstractions (Carpenter, Just \& Shell, 1990) and comprised of different factors. Van der Ven \& Ellis (2000) emphasized that the RSPM contains two significant factors. First one is identified as gestalt continuation which presents in the initial items for which the correct solution must be found according to some gestalt continuation rule and cognition of figural relations. Second factor is analogical reasoning, present in most of the later items. The subject should deduce and use analogical reasoning to find out the rules in certain changes. According to another study, RSPM was comprised of three factors namely gestalt continuation, verbal-analytical reasoning and visuospatial ability (Lynn, Allik \& Irwing, 2004). Particularly in RSPM, while perceiving or imagining spatial forms, test taker needs to rotate them in two- or three-dimensions and find out the creative solution in any field of knowledge before matching a spatial form with another one correctly.

Over time, an extensive literature has developed on creativity and intelligence. Although the divergent thinking tests and general intelligence tests such as RSPM both encompass a strong visual imagery and visuospatial component, only a few studies focused this relationship in the literature. For instance, according to more recent theories, spatial abilities are considered as an important process both for intelligence creative thinking (Lohman, 2000; Palmiero \& Srinivasan, 2015). Within executive functions, other related factors such as fluid intelligence, and creativity was defined by Benedek and colleagues (2014). They investigated whether the fluid intelligence and creativity can be explained by a common executive ability. They have found that while fluid intelligence was strongly predicted by updating (component of working memory); creativity was predicted by both updating and inhibition processes. In addition, updating which is a highly correlated ability with working memory was found to explain the relevant part of the shared variance between intelligence and creativity. The researchers have concluded that executive functions contribute to the performance in both (Benedek, et al 2014).

Creativity is associated with different cognitive abilities, such as cognitive flexibility, fluency, working memory and attention which are mostly regulated by the prefrontal cortex (Dietrich, 2004). The ability to change traditional or conventional thinking strategies to adopt new and high-level rules is the most important feature of creativity theories and the concept of divergent thinking (Kim, 2005). However, some studies view intelligence and creativity as two distinct modestly correlated cognitive abilities (Barron \& Harrington, 1981; Wallach \& Kogan, 1965; Nusbaum \& Silvia, 2011). The current study was designed in accordance with "divergent thinking theory" of creativity (Guilford, 1967). Since the relationship between creativity and fluid intelligence has been unclear (Kaufman \& Plucker, 2011) we aimed to examine the possible associations between these two constructs in young adults. Study addresses the following research question: Does significant correlation exist between factors of fluid intelligence and dimensions of creativity?

\section{Method}

\section{Research Design}

In order to explore the relationship between fluent intelligence and creative we used correlational method (explanatory research design). A correlation is a statistical test to determine the tendency or pattern for two (or more) variables or two sets of data to vary consistently. By using this research approach, we tested whether the changes in fluent intelligence reflected to the changes in creativity.

\section{Participants}

The sample consisted of 26 volunteer participants (male:11; female:15) studying at state universities of Turkey. None of the subjects had a history of neurological or psychiatric illness. They were recruited 
through convenience sampling method. The mean age of the group was $(M=25.03, S D=2.87)$.

\section{Assessment Devices}

\section{The Raven Standard Progressive Matrices (RSPM)}

RSPM is a standardized general intelligence test that consists of 60 visually presented, geometric- parallel items (Raven, Raven, \& Court, 1996). The test comprises of 5 sets (A, B, C, D and E) which contain 12 items in each set. The $A$ and $B$ sections each contain 12 2x2 matrices, while the $\mathrm{C}, \mathrm{D}$, and $\mathrm{E}$ sections each contain 12 $3 \times 3$ matrices. Section A involves finding the missing part of an image by using gestalt compositions. The other sections the solutions become more complicated and require more abstract reasoning. The correct answer should be selected from a group of 6 possible answers, or a group of 8 possible answers (Lynn, 2004). The items are getting more and more difficult in each section and the solution of items require higher cognitive functions such as reasoning, abstraction skills, visual-spatial abilities, working memory, analytical thinking and fluent intelligence. It was standardized for the Turkish sample by Karakaş in 2004 .

Previous research described three different factors for RSPM (Lynn, 2004). The first factor is "gestalt continuation", which requires the perception of the pattern as gestalt completion and selecting the appropriate piece without the use of reasoning. The second factor is "verbal analytic reasoning", which requires verbal reasoning, arithmetical addition and subtraction operations. The third factor is "visuospatial ability" in which the solutions of the items require perceptual abilities and visuospatial reasoning. In this study items were selected from the last two factors. In the present study, a nine-item short form from sets C, D and $\mathrm{E}$ was used in order to evaluate fluid intelligence.

\begin{abstract}
Assessment Of Creativity
In this study three test composed of three different questions were used to assess divergent thinking (Guilford, 1967; Silvia, 2008; Chermahini, Hickendorff $\&$ Hommel, 2012). The unusual uses test requires generating creative uses of a brick; the object instances test requires generating creative instances of things that are round, and the consequences test requires imagining how different would life be if there is no need to sleep. All the subjects were instructed that the test was measuring creative thinking. The instructions of the three questions are presented in Table 1. Unlike phonetic fluency tests (e.g., list as many words that start with $\mathrm{F}$ as you can) and semantic fluency tests (e.g., list as many animals as you can), divergent thinking tests were expected to evaluate the creative quality of the responses, not merely the number of responses (Silvia, 2008).
\end{abstract}

Table 1. The instructions of divergent thinking tests.

\begin{tabular}{|l|l|}
\hline The unusual uses test & $\begin{array}{l}\text { You should write down all the original and creative uses for a brick that you can think of. } \\
\text { Certainly, there are common, unoriginal ways to use a brick; for this test, write down all the } \\
\text { unusual, creative, and uncommon uses you can think of. You have three minutes. Any } \\
\text { questions? }\end{array}$ \\
\hline The object instances test & $\begin{array}{l}\text { You should write down all the original and creative instances of things that are round that you } \\
\text { can think of. Certainly, there are some obvious things that are round; for this test, write down } \\
\text { all the unusual, creative, and uncommon instances of the things that are round. You have three } \\
\text { minutes. Any questions? }\end{array}$ \\
\hline The consequences test & $\begin{array}{l}\text { Imagine that people do not need sleep anymore and will not experience any adverse outcomes. } \\
\text { What would happen if humans didn't have to sleep and how different would life be? Write } \\
\text { down all the original, creative consequences of it? You have three minutes. Any questions? }\end{array}$ \\
\hline
\end{tabular}

The answers were identified and scored according to four categories: originality, fluency, flexibility, elaboration dimension (Chermahini, 2012; Silvia, 2011; Takeuchi, 2010). A brief description of each category is given below.

Originality: Each response was compared to the total amount of responses from all the participants. Unique responses tended to be creative responses, but a response given only once not always judged to be as creative. Responses that were given by only $5 \%$ of the group counted as unusual (1 point) and responses given by only $1 \%$ of them count as unique ( 2 points). The responses which had high frequency rate were accepted as a common response.

Fluency: Fluency was measured by the number of unique relevant responses to questions and was related to the ability of generating many alternative answers. Fluency scores were determined by the total number of questions answered after excluding inappropriate responses or answers that are difficult to relate to the subject.

Flexibility: Flexibility was the ability to create answers from a broad perspective. Flexibility scores were determined by the sum of the total number of different category types.

Elaboration: The amount of detail in the given responses were analyzed; e.g., "a doorstop" counts 0 , whereas "a door stops to prevent a door slamming shut in a strong wind" counts 2 (1 point for explanation of door slamming and another for further detail about the wind).

\section{Procedure}

All participants were instructed about the procedures of the study and their consent was taken. Thereafter, standard instruction of the RSPM test was given by the experimenter and the items from sets C ( 3 items), D (3 items), E (3 items) were presented in the centre of a laptop screen according to the original order of the items. The nine items were selected from the verbal-analytic, visuo-spatial and the combined factors of the RSPM identified by Lynn and colleagues (2004). The statistical analyses were made both with the total score from the 9 items, and the three factors. After completing RSPM, three questions of the divergent thinking test were given 
in a written form and asked to the subjects to write their answers on the paper.

The procedures of the study:

(a) Standard instructions were given by the experimenter and the participants completed the three items of part A version as practice items from the paper-pen version.

(b) The participants were then seated in front of a laptop. Standard RSPM instructions were given again by the experimenter and the participants were asked to complete the 9 items test.

(c) After the RSPM was administered, participants were given the divergent thinking tests in which generating creative and unusual answers were expected.

\section{Statistical Analysis}

Statistical analyses were performed using the Statistical Package for the Social Sciences (SPSS) Ver. 20 (SPSS IBM Corp.; Armonk, NY, USA) statistical package program. Pearson's correlation analysis was performed to determine the correlation between RSPM factors and divergent thinking characteristics. For the statistical analysis, a $\mathrm{p}<0.05$ was considered statistically significant.

\section{Results}

In order to measure fluid intelligence and reasoning a nine form of RSPM was administered. The creativity was measured by the divergent thinking tests comprised of unusual uses test, object instances test, and consequences test. To evaluate the difficulty of each item we calculated percentages of response accuracy. We found that the highest and the lowest correct responded items were belonging to the $5^{\text {th }}$ and $11^{\text {th }}$ items of set E, respectively (Table 2). We applied Pearson's correlation statistics to investigate whether there was an association between participants' divergent thinking performance and scores of RSPM. Significant moderate correlations were found between RSPM visuospatial factor and fluency (unusual uses test) $(r=.41, p<.05)$, (object instances test) $(r=.50$, $\mathrm{p}<.01)$ and flexibility (object instances test) ( $\mathrm{r}=.42$, $\mathrm{p}<.05$ ) subtests of divergent thinking (Table3; Table 4).

Table2. The accuracy rates of each RSPM items.

\begin{tabular}{|l|l|l|l|l|}
\hline Items & $\begin{array}{l}\text { Answers } \\
\text { Correct }\end{array}$ & $\begin{array}{l}\text { Percentage of correct } \\
\text { answers }\end{array}$ & RSPM factors \\
\hline C12 & 16 & 10 & 61.5 & Verbal analytic \\
\hline C11 & 22 & 4 & 84.6 & Verbal analytic \\
\hline C6 & 24 & 2 & 92.3 & Visuospatial \\
\hline D11 & 16 & 10 & 61.5 & Verbal analytic \\
\hline D9 & 20 & 6 & 76.9 & Visuospatial \\
\hline D8 & 24 & 2 & 92.3 & Visuospatial \\
\hline E11 & 3 & 23 & 11.5 & Verbal analytic, visuospatial \\
\hline E6 & 21 & 5 & 80.8 & Verbal analytic, visuospatial \\
\hline E5 & 26 & 0 & 100 & Verbal analytic, visuospatial \\
\hline
\end{tabular}

RSPM: Raven standard progressive matrices

Table3. Summary of Pearson's Correlation Coefficients

\begin{tabular}{|l|l|l|l|l|}
\hline & RSPM total & RSPM VS & RSPM VA & VS+VA \\
\hline Originality (unusual uses) & -.069 & -.058 & .026 & -.122 \\
\hline Originality (instances) & -.254 & -.174 & -.160 & -.195 \\
\hline Originality (consequences) & .062 & -0.77 & -.020 & .248 \\
\hline Fluency (unusual uses) & .178 & $.411^{*}$ & -.057 & .007 \\
\hline Fluency (instances) & .345 & $.505^{*} *$ & .148 & .042 \\
\hline Fluency (consequences) & .089 & .282 & -.058 & -.049 \\
\hline Flexibility (unusual uses) & .043 & .313 & -.127 & -.107 \\
\hline Flexibility (instances) & .169 & $.425^{*}$ & .051 & -.154 \\
\hline Flexibility (consequences) & .084 & .217 & .015 & -.071 \\
\hline Elaboration (unusual uses) & -.175 & -.108 & -.211 \\
\hline Elaboration (instances) & -.007 & -.199 & -.060 \\
\hline Elaboration (consequences) & -.037 & -.021 & .287 \\
\hline
\end{tabular}

*p < 0.05; **p < 0.01 RSPM: Raven standard progressive matrices, VS: Visuo-spatial, VA: Verbal analytic

Table4. Summary of Pearson's Correlations Coefficients

\begin{tabular}{lllll}
\hline & Originality & Fluency & Flexibility & Elaboration \\
\hline RSPM total & -.106 & .267 & .169 & -.175 \\
RSPM VS & -.142 & $.472^{*}$ & $.417^{*}$ & -.274 \\
RSPM VA & -.067 & .066 & .068 & -.275 \\
VS+VA & -.003 & -.001 & .165 & .149 \\
\hline
\end{tabular}

*p < 0.01 RSPM: Raven standard progressive matrices, VS: Visuo-spatial, VA: Verbal analytic

\section{Discussion}

We did not find any significant correlation between the total score of RSPM and the tests used to measure divergent thinking. Our results indicated that the second (object instances: round shapes) and the third (unusual uses: brick) tests of the divergent thinking were significantly and positively correlated with RSPM's 
visuospatial factor. In other words, the magnitude of correlations found to be significant between the visuospatial component of the fluent intelligence (RSPM) and both fluency, flexibility dimensions of the creativity.

The RSPM was reported as one of the multidimensional structured tests in the literature (DeShon, Chan \& Weissbein, 1995, Lynn, 2004). As discussed in the introduction section, according to Lynn and colleagues' findings (2004), RSPM was comprised of three factors. In the current study we focused on the second and third factors which were defined as "verbal analytic reasoning" and the "visuospatial ability", respectively. The reason we chose test items from different factors of RSPM (instead of using only RSPM total score) was that we had the opportunity to explore all possible relationships.

Visuo-spatial items of the RSPM which requires to perceive and manipulate visual patterns found to be associated with the fluency and flexibility scores of the second (object instances: round shapes) and the third (unusual uses: brick) questions of the test. We conclude that the cognitive components of fluid intelligence and creativity tests may share some common cognitive processes. Regarding RSPM's factors, verbal-analytic reasoning mostly benefits from feature integration and hypothesis testing, whereas the visuospatial reasoning mostly benefits from elaborate perception to stimulus features (Chen, Beuckelaer, Wang, \& Liu, 2017). Like RSPM's visuospatial reasoning, divergent thinking also requires using the geometrical features of the objects (brick and round shapes) to create new and unusual items.

In addition, solution of the items regarding to visuospatial factor may involve mental operations or abilities such as rapidly perceiving and manipulating visual patterns and visual imagery of these patterns. As suggested in the literature RSPM performance is determined by a mental imagery approach based on visual representation (DeShon, 1995). which also appears to be critical while performing a divergent thinking test. The literature review shows that mental imagery and divergent thinking are related to each other (LeBoutillier $\&$ Marks, 2003). The contribution of visual imagery to creativity have been supported by findings of positive associations between visual imagery ability and visual, verbal creative ability (Palmiero, Cardi, \& Belardinelli, 2015). In a recent study Benedek's and colleagues (2020) have focused on the neural correlates of creative thought. They have found that generation of original versus common associations was related to higher activation in bilateral lingual gyri. They have suggested that cued search for remote representatives of given properties are supported by visually mediated search strategies. In addition, they have suggested that generation of verbally cued, original associations relies not only on verbal semantic memory but involves mental imagery and episodic simulation.

Recent studies show that divergent thinking and intelligence are overlapping with other cognitive functions (Plucker \& Esping, 2015; Takeuchi, 2011). One of these functions is executive functions which have an important role in cognitive basis of individual differences in intelligence and creative thought. Fluency and flexibility are the two components of executive functions. Intelligence and creativity are thought to be correlated constructs and considered to have common executive components (Benedeck, Jauk, Sommer, Arendasy, \& Neubauer, 2014). RSPM, a commonly used test in the literature for fluid intelligence and reasoning, includes capabilities such as flexible mind, inference rules, evaluating target hierarchies, and making high level abstractions. Neural connections for these abilities are thought to cover a wide frontoparietal network, different processing models emphasize varying proportions of specific roles of prefrontal or posterior regions. In a recent study it was found that intelligence and creativity rely on similar neural and cognitive systems. It was reported that a network that predicted general intelligence shared over half of its functional connections with a network that predicted creative ability which were linking frontal executive regions with posterior default regions (Frith, 2019).

The current study presents some limitations such as, the usual way of assessing and scoring divergent thinking may involve methodological problems. Divergent thinking tests could be scored in many ways and to an extent they have reliability problems (Silvia, 2008). Moreover, it is important to point out that creativity is a complex construct that is unlikely to be fully measured by a single test (Nasbaum \& Silvia, 2011). For instance, some researchers consider creativity an attribute of a product while others consider it as a trait or state of an individual (Runco, 2007). Our study results also support the idea that there is not one single aptitude or factor for creativity. Another limitation was all the participants were university students therefore, the results had poor generalizability. Lastly, the sample size was too small, and we did not administer 60-item set of RSPM. However, we used a computerised version of RSPM where other studies did not find any significant difference across administrations or formats (Williams \& McCord, 2007).

In general, the size of the correlation between intelligence and creativity seems to depend on the task or tests used to measure creativity or intelligence. In addition, the strongest positive relationship usually obtain from the studies which use latent variables such as creative achievement (Jauk, Benedek, \& Neubeuer, 2014), and when the performance evaluated by the creative quality of generated ideas (Nusbaum, Silvia, \& Beaty., 2014). Since creativity is a multifaceted construct a more comprehensive assessment tool may be more helpful to explore the possible relationship. Therefore, we must keep in mind that results might change depending on the tasks used both to measure creativity and intelligence. In conclusion, the current study findings showed that the two executive components of creativity, namely fluency and flexibility were associated with visuospatial reasoning factor of the fluent intelligence test. Future research should consider the potential effects of other cognitive domains such as problem solving, working memory, cognitive control, and focus on how these skills can be integrated into real life situations. 


\section{References}

Abraham, A., \& Windmann, S. (2007). Creative cognition: the diverse operations and the prospect of applying a cognitive neuroscience perspective. Methods 42, 38-48.

Barron, F. (1969). Creative person and creative process. New York: Holt, Rinehart \& Winston.

Barron, F., \& Harrington, D. M. (1981). Creativity, intelligence, and personality. Annual Review of Psychology, 32, 439-476.

Benedek, M., Jauk, E., Sommer, M., Arendasy, M., \& Neubauer, A. C. (2014). Intelligence, creativity, and cognitive control: The common and differential involvement of executive functions in intelligence and creativity. Intelligence, 46, 73-83.

Benedek, M., Jurisch, J., Koschutnig, K., Fink, A., Beaty, R.E. (2020). Elements of creative thought: Investigating the cognitive and neural correlates of association and bi-association processes NeuroImage, 210, 1-10.

Bilker, W. B., Hansen, J. A., Brensinger, C. M., Richard, J., Gur, R. E., \& Gur, R. C. (2012). Development of abbreviated nine-item forms of the Raven's standard progressive matrices test. Assessment, 19(3), 354-369.

Carpenter, P. A., Just, M. A., \& Shell, P. (1990). What one intelligence test measures: A theoretical account of the processing in the Raven Progressive Matrices Test. Psychological Review, 97(3), 404-431.

Cattell RB (1967) The theory of fluid and crystallized general intelligence checked at the 5-6 year-old level. $\mathrm{Br} J \mathrm{Educ}$ Psychol,37(2), 209-24.

Chen, Z., De Beuckelaer, A., Wang, X. \& Liu, J. (2017). Distinct neural substrates of visuospatial and verbal-analytic reasoning as assessed by Raven's Advanced Progressive Matrices. Sci Rep 7, 16230.

Chermahini S.A., Hickendorff M., \& Hommel B. (2012) Development and validity of a Dutch version of the Remote Associates Task: An item-response theory approach. Thinking Skills and Creativity, 7, 177-186.

DeShon, R. P., Chan, D. \& Weissbein, D. A. (1995). Verbal overshadowing effects on Raven's Advanced Progressive Matrices: evidence for multidimensional performance determinants. Intelligence, 21, 135-155.

Dietrich, A. (2004). The cognitive neuroscience of creativity. Psychonomic Bulletin \& Review, 11, 1011-1026.

Downey L.A., Lomas J., Billings C., Hansen K., \& Stough C. (2014). Scholastic success: Fluid intelligence, personality, and emotional intelligence. Canadian Journal of School Psychology, 29 (1), 40-53.

Gray, J. R., \& Thompson, P. M. (2004). Neurobiology of intelligence: Science and ethics. Nature Reviews Neuroscience, $5,471-482$.

Guilford, J. P. (1967). The nature of human intelligence. New York: McGraw-Hill.

Frith, E., Elbich, D., Christensen, A. P., Rosenberg, M. D., Chen, Q., Silvia, P., ... Beaty, R. (2019). Intelligence and Creativity Share a Common Cognitive and Neural Basis.

Karakaş S. (2004) BILNOT battery: research and development of neuropsychological tests. Ankara: Dizayn Ofset (in Turkish).

Kaufman J.C., Plucker J.A., \& Baer J. (2008). Essentials of creativity assessment. Wiley \& Sons.

Kim K.H. (2005) Can only intelligent people be creative? Journal of Secondary Gifted Education, 16, 57-66.
Lynn, R., Allik, J., \& Irwing, P. (2004). Sex differences on three factors identified in Raven's Standard Progressive Matrices. Intelligence, 32, 411-424.

Jauk E, Benedek M, Dunst B, Neubauer AC. (2013) The relationship between intelligence and creativity: new support for the threshold hypothesis by means of empirical breakpoint detection. Intelligence, 41(4), 212-221.

Jauk, M. Benedek, A.C. Neubauer (2014) The road to creative achievement: A latent variable model of ability and personality predictors. European Journal of Personality, 28, 95-105.

LeBoutillier, N., \& Marks, D.F. (2003). Mental imagery and creativity: a meta-analytic review study. British Journal of Psychology 94: 29-44.

Lohman, D.F. (2000). Complex information processing and intelligence. In R.J. Sternberg (Ed.), Handbook of Intelligence (pp-340). New York, NY, US: Cambridge University Press.

Nusbaum E.C., Silvia P.J (2011), Are intelligence and creativity really so different? Fluid intelligence, executive processes, and strategy use in divergent thinking. Intelligence, 39. 36-45.

Nusbaum, E. C., Silvia, P. J., \& Beaty, R. E. (2014). Ready, set, create: What instructing people to "be creative" reveals about the meaning and mechanisms of divergent thinking. Psychology of Aesthetics, Creativity, and the Arts, 8(4), 423-432

Palmiero M., Nori R., Aloisi V., Ferrara M., \& Piccardi L. (2015). Domain-specificity of creativity: A study on the relationship between visual creativity and visual mental imagery. Frontiers in Psychology, 6, 1870

Plucker, J.A., \& Esping, A. (2015). Intelligence and creativity: A complex but important relationship. Asia Pacific Education Review, 16, 153- 159 .

Plucker, J. A., Esping, A., Kaufman, J. C., \& Avitia, M. J. (2014). Creativity and intelligence. In S. Goldstein, D. Princiotta, \& J. A. Naglieri (Eds.), Handbook of intelligence (pp. 283-294). New York, NY: Springer.

Raven, J., Raven, J. C., \& Court, J. H. (1996). Manual for Raven's Progressive Matrices and Vocabulary Scales. Oxford: Oxford Psychologists Press.

Runco, M. A. (2007). Creativity. San Diego, CA: Academic Press.

Palmiero M., Srinivasan N. (2015). Creativity and spatial ability: a critical evaluation. In Manjaly J., Indurkhya B. (Eds.) Cognition, Experience and Creativity, (p.p.189-214). New Delhi: Orient Blackswan.

Shi, B., Wang, L., Wang, J., Zhang, M., \& Xu, L. (2017). Relationship between divergent thinking and intelligence: An empirical study of the threshold hypothesis with Chinese children. Frontiers in Psychology, 8, 254.

Silvia, P. J. (2008). Another look at creativity and intelligence. Exploring higher order models and probable confounds. Personality and Individual Differences, 44, 1012-1021.

Silvia, P. J., Winterstein, B. P., Willse, J. T., Barona, C. M., Cram, J. T., Hess, K. I., \&... Richard, C. A. (2008). Assessing creativity with divergent thinking tasks: Exploring the reliability and validity of new subjective scoring methods. Psychology of Aesthetics, Creativity, and the Arts, 2, 68-85.

Silvia, P. J. (2011). Subjective scoring of divergent thinking: Examining the reliability of unusual uses, instances, and consequences tasks. Thinking Skills and Creativity, 6(1), 24-30.

Spearman, C. and Wynn-Jones, L. (1951). Human ability. London: Macmillan. 
Sternberg, R. J. \& Lubart, T. I. (1996). Investing in creativity. American Psychologist, 51(7), 677-688.

Sternberg, R. J. (1999). The theory of successful intelligence. Review of General Psychology, 3, 292-316.

Sternberg, R. J., \& Kaufman, S. B. (2011). Cambridge handbook of intelligence. New York, NY: Cambridge University Press.

Takeuchi H., Taki Y., Sassa Y., Hashizume H., Sekiguchi A., Fukushima A., \& Kawashima R. (2010). White matter structures associated with creativity: evidence from diffusion tensor imaging. Neuroimage, 51, 11-18.

Takeuchi H, Taki Y, Hashizume H, Sassa Y, Nagase T, Nouchi R, Kawashima R (2011) Failing to deactivate: the association between brain activity during a working memory task and creativity. Neuroimage, 55, 681-687.

Wallach, M. A., \& Kogan, N. (1965). Modes of thinking in young children: A study of the creativity-intelligence distinction. New York, NY: Holt, Rinehart \& Winston.

Williams, J.E. \& McCord M.D. (2006) Equivalence of standard and computerized versions of the Raven Progressive Matrices Test. Computers in Human Behaviour, 22(5), 791-800.

Van der Ven, A.H.G.S., \& Ellis, J. L. (2000). A Rasch analysis of Raven's standard progressive matrices. Personality and Individual Differences, 29, 45 - 64 . 